\title{
Hubungan Antara Pemahaman Sejarah Nasional Indonesia dan Wawasan Kebangsaan Dengan Karakter Mahasiswa (Studi Pada Mahasiswa Pendidikan Sejarah FKIP Universitas Galuh Ciamis)
}

\author{
Yadi Kusmayadi*
}

\begin{abstract}
Abstrak
Penelitian Kuantitatif ini bertujuan untuk mengungkap tingkat hubungan pemahaman sejarah nasional Indonesia dan wawasan kebangsaan terhadap karakter mahasiswa. Hipotesisnya adalah (1). terdapat hubungan antara pemahaman sejarah nasional indonesia dengan karakter mahasiswa, (2). terdapat hubungan antara wawasan kebangsaan dengan karakter mahasiswa, (3). terdapat hubungan pemahaman sejarah nasional indonesia dan wawasan kebangsaan secara bersama-sama dengan karakter mahasiswa. Subjek penelitian adalah mahasiswa Pendidikan Sejarah FKIP Universitas Galuh Ciamis tingkat III semester 6 dan tingkat IV semester VIII. Pengumpulan data menggunakan instrumen tes, dan angket.Teknik analisis data menggunakan analisis korelasi, regresi sederhana dan regresi ganda pada taraf signifikansi $5 \%$.

Hasil penelitian menunjukkan (1) terdapat hubungan positif yang signifikan antara Pemahaman SNI $\left(X_{1}\right)$ dengan karakter mahasiswa $(Y)$ dapat diterima dengan koefisien korelasi sebesar 0.590, koefisien regresi sebesar 0.159 pada konstanta 100.876 dan $t_{\text {hit }}$ (5.535) $>t_{\text {tab }}$ (1.663) dengan taraf signifikansi 5\%; (2) terdapat hubungan positif yang signifikan antara wawasan kebangsaan $\left(X_{2}\right)$ dengan karakter mahasiswa ( $Y$ ) dapat diterima dengan koefisien korelasi sebesar 0.604 , koefisien regresi sebesar 0.442 pada konstanta 52.272 dan $t_{\text {hit }}(6.867)$ $>t_{\text {tab }}(1.663)$ dengan taraf signifikansi 5\%; (3) terdapat hubungan positif yang signifikan pemahaman SNI $\left(X_{1}\right)$ dan wawasan kebangsaan $\left(X_{2}\right)$ secara bersamasama dengan karakter mahasiswa $(Y)$ dapat diterima dengan koefisien korelasi sebesar 0.605, koefisien regresi pemahaman SNI sebesar 0.079, koefisien regresi wawasan kebangsaan sebesar 0.441 pada konstanta 50.215, koefisien determinasi sebesar 0.366 dengan persamaan gars regresi ganda $\hat{Y}=50.215+$ $0.079 X_{1}+0.441 X_{2}$ dan $F_{\text {hit }}(23.376)>F_{\text {tab }}$ (3.111) dengan taraf signifikansi $5 \%$.
\end{abstract}

\section{Kata Kunci: Sejarah Nasional Indonesia, Wawasan Kebangsaan, Karakter}

\section{Pendahuluan}

Fase kemerdekaan yang sedang diisi oleh bangsa Indonesia, berbagai perubahan yang mendasar telah dilahirkan.Situasi, kondisi, dan tantangan yang dihadapi tidak hanya menyangkut bidang politik, tetapi juga keseluruhan bidang kehidupan. Hal ini menuntut partisipasi seluruh bangsa Indonesia dan terlebih pada generasi muda karena para generasi muda ini merupakan generasi penerus untuk mengisi dan mempertahankan kemerdekaan Indonesia.

Isu yang sekarang terjadi adalah kekhawatiran sebagian orang bahwa karakter bangsa sedang mengalami erosi. Gejala ini terutama nampak di kalangan generasi muda yang cenderung terlibat dalam berbagai kegiatan yang bercorak 
solidaritas sektarian, individualisme dan primordialisme. Keterikatan primordial menjadi negatif apabila tidak lagi terikat ke dalam wawasan kebangsaan maupun nilainilai kemanusiaan yang universal. Penghargaan terhadap nilai-nilai kemanusiaan dan kesadaran kebangsaan merosot, keterikatan primordial menjadi primordialisme eksklusif.

Oleh karena itu, tepat jika primordialisme dan keterlibatan hati eksklusif pada tatanan asli yaitu suku, etnik, ras, dan agama yang tidak lagi merupakan kebanggaan dan kegembiraan nasional, dianggap ancaman paling serius bagi persatuan dan kesatuan, seperti eksistensi bangsa dan negara Indonesia.

Kebangkitan nasional 20 Mei 1908 dan sumpah pemuda 28 Oktober 1928 memperlihatkan wawasan kebangsaan dalam tekad dan keinginan membangun persatuan dan kesatuan karena menyadari adanya kebhinekaan dan keragaman budaya, agama, etnis, dan suku yang akhirnya menuju kepada perjuangan kemerdekaan nasional.

Keanekaragaman suku, agama, ras dan adat istiadat yang dulu terjalin kokoh dan kuat dalam bingkai kebangsaan Indonesia, kini terasa semakin longgar dan rentan terhadap masuknya pengaruh nilainilai universal yang tidak sesuai dengan nilai-nilai dan norma-norma yang berlaku di Indonesia merupakan dampak dari perubahan yang tidak dapat terhindari.
Pemantapan wawasan kebangsaan dalam menghadapi perkembangan global dan disintegrasi bangsa. Adapun wawasan kebangsaan sendiri mempunyai komitmen yang menjunjung tinggi hak dan kewajiban setiap warga negara, ditetapkan melalui proses politik yang konstitusional dan dilaksanakan dengan konsekuensi hukum yang tinggi.

Wawasan kebangsaan tumbuh sebagai identitas diri dari proses sejarah dan juga pola budaya yang bersifat majemuk dan beraneka ragam, tetapi tetap dalam kesatuan. Pembentukan jiwa patriotik, cinta tanah air dan rela berkorban merupakan kewajiban bagi setiap warga negara.

Oleh karena itu, perlu ditanamkan sejak kecil pada setiap diri generasi penerus, mengingat generasi muda khususnya mahasiswa pada titik persimpangan budaya berbagai bangsa yang semakin transparan memungkinkan mereka kehilangan nilai pegangan hidup, serta tidak jelasnya identitas diri. Pencarian patokan nilai yang dapat menjadi bahan renungan untuk mempertebal jati diri bangsa sulit ditemukan.

Hal itu merupakan keprihatinan semua pihak dalam menyongsong era global yang membutuhkan identitas dalam mempertahankan integritas bangsa bagi percaturan global. Di lain pihak, ilmu pengetahuan dan teknologi diakui berperan penting dalam menjawab persoalan- 
persoalan dan tuntutan yang timbul sebagai akibat dari proses pembangunan, modernisasi dan globalisasi yang bersifat kompleks dan global.

Globalisasi telah menimbulkan dampak yang begitu besar dalam dimensi kehidupan manusia karena globalisasi merupakan proses internasionalisasi seluruh tatanan masyarakat modern, sehingga terjadi dampak yang beragam terutama pada aspek sosial, dampak positifnya kemajuan teknologi komunikasi dan informasi mempermudah manusia dalam berinteraksi dengan manusia lainnya Ohmae (2002:19). Dampak negatifnya adalah banyak nilai dan budaya masyarakat yang mengalami perubahan dengan cara meniru atau menerapkan secara selektif, salah satu contoh dengan hadirnya modernisasi timbul sifat ingin serba mudah (instant) pada diri seseorang.

Pada sebagian masyarakat, juga sudah banyak yang mengikuti nilai-nilai budaya luar yang dapat terjadi dehumanisasi yaitu derajat manusia nanti tidak dihargai karena lebih banyak menggunakan mesinmesin berteknologi tinggi. Hal yang demikian, sebab kurangnya pemahaman terhadap sejarah dan lunturnya wawasan kebangsaan yang mempengaruhi terhadap karakter bangsa diantaranya mahasiswa lebih senang dengan musik aliran barat daripada seni lokal seperti wayang, campur sari ataupun tarian daerah, begitu pula desain pakaian baik laki-laki atau perempuan mengikuti kebarat-baratan. Generasi muda terutama mahasiswa yang menjadi tumpuan di masa depan serta tanggung jawab dan kedisiplinan nasional dapat tertanam kuat serta dalam hal berperilaku diakui dalam kelompoknya, meskipun kadang dijumpai perilaku yang kurang sesuai.

Melalui pendidikan yang diterima, baik pendidikan formal, maupun kegiatan organisasi lain, para mahasiswa diharapkan dapat menjadi manusia Indonesia yang berjiwa pancasila berwawasan ke depan secara positif dan menjadi warga negara Indonesia yang mempunyai sikap untuk membela negaranya dalam berbagai bidang kehidupan. Mahasiswa sebagai bagian dari generasi muda yang juga merupakan warga negara hendaknya memberikan rasa percaya pada masyarakat bahwa merekalah yang menggantikan tongkat estafet kepemimpinan bangsa ini di kemudian hari.

Peran mahasiswa sebagai aktor pembawa perubahan (agent of changes) tidak diragukan lagi, sebab di negara mana pun di dunia ini, mahasiswa tampil sebagai pionir pembaharuan dalam suatu negara, termasuk Indonesia. Oleh karena itu, mahasiswa harus memiliki sikap dan perilaku yang positif, kreatif, kritis, kooperatif, dan etis. Sikap dan perilaku ini sangat dibutuhkan untuk menghadapi persaingan yang semakin ketat di era global, sehingga pembinaan karakter mahasiswa 
diperlukan untuk menunjukkan nilai-nilai yang berbasis karakter.

Hal ini sejalan dengan model pendidikan karakter yang ditawarkan oleh Healea (2006) yaitu dengan membentuk divisi kemahasiswaan yang bertanggungjawab untuk berbagai macam program, kebijakan, dan sumber daya yang berfungsi membentuk pengalaman di perguruan tinggi bagi mahasiswa. Karakter yang baik digambarkan sebagai perilaku yang konsisten menerapkan prinsip-prinsip seperti menghargai orang lain, kejujuran, keadilan, dan tanggungjawab ketika menghadapi pilihan perilaku dan etika (Lickona dalam Skaggs \& Bodenhorn, 2006).

Pendidikan karakter saat ini menjadi isu utama pendidikan, selain menjadi bagian dari proses pembentukan akhlak anak bangsa, pendidikan karakter yang diharapkan mampu menjadi pondasi utama dalam mensukseskan Indonesia Emas 2025. Dalam UU No. 20 Tahun 2003 Tentang sistem pendidikan nasional pasal 3, menyebutkan bahwa:

Pendidikan nasional berfungsi mengembangkan kemampuan dan membentuk karakter serta peradaban bangsa yang bermartabat dalam rangka mencerdaskan kehidupan bangsa. Pendidikan nasional bertujuan untuk berkembangnya potensi peserta didik agar menjadi manusia yang beriman dan bertaqwa kepada Tuhan Yang Maha Esa, berakhlak mulia, sehat, berilmu, cakap, kreatif, mandiri, dan menjadi warga negara yang demokratis serta bertanggung jawab.
Selanjutnya pada pasal 13 Ayat 1 menyebutkan bahwa Jalur pendidikan terdiri atas pendidikan formal, non-formal, dan informal dapat saling melengkapi dan memperkaya. Pendidikan informal adalah jalur pendidikan keluarga dan lingkungan. Pendidikan informal sesungguhnya memiliki peran dan kontribusi yang sangat besar dalam keberhasilan pendidikan. Peserta didik mengikuti pendidikan di sekolah hanya sekitar 7 jam per hari, atau kurang dari 30\%. Selebihnya (70\%), peserta didik berada dalam keluarga dan lingkungan sekitarnya.Jika dilihat dari aspek kuantitas waktu, pendidikan di sekolah berkontribusi hanya sebesar $30 \%$ terhadap hasil pendidikan peserta didik.

Selama ini, pendidikan informal terutama dalam lingkungan keluarga belum memberikan kontribusi berarti dalam mendukung pencapaian kompetensi dan pembentukan karakter peserta didik. Kesibukan dan aktivitas kerja orang tua yang relatif tinggi, kurangnya pemahaman orang tua dalam mendidik anak di lingkungan keluarga, pengaruh pergaulan di lingkungan sekitar, dan pengaruh media elektronik berpengaruh negatif terhadap perkembangan dan pencapaian hasil belajar.

Salah satu alternatif untuk mengatasi permasalahan tersebut adalah melalui pendidikan karakter terpadu, yaitu memadukan dan mengoptimalkan kegiatan pendidikan informal lingkungan keluarga dengan pendidikan formal di sekolah. Dalam 
hal ini, waktu belajar di sekolah perlu dioptimalkan agar peningkatan mutu hasil belajar dapat dicapai, terutama dalam pembentukan karakter peserta didik.

Dengan demikian, fungsi dan tujuan pendidikan di setiap jenjang berkaitan dengan pembentukan karakter peserta didik sehingga mampu bersaing, beretika, bermoral, sopan santun dan berinteraksi dengan masyarakat. Hal ini dapat dibuktikan dari hasil penelitian di Harvard University Amerika Serikat (Retno Susanti, 2011: 3), menunjukkan bahwa:

Ternyata kesuksesan seseorang tidak ditentukan semata-mata oleh pengetahuan dan kemampuan teknis (hard skill) saja, tetapi lebih oleh kemampuan mengelola diri dan orang lain (soft skill). Penelitian ini mengungkapkan, bahwa kesuksesan hanya ditentukan sekitar 20 persen oleh hard skill dan sisanya 80 persen oleh soft skill. Bahkan orang-orang tersukses di dunia bisa berhasil dikarenakan lebih banyak didukung kemampuan soft skill daripada hard skill.

Hal ini mengisyaratkan bahwa mutu pendidikan karakter peserta didik sangat penting untuk ditingkatkan. Karakter merupakan nilai-nilai perilaku manusia yang berhubungan dengan Tuhan Yang Maha Esa, diri sendiri, sesama manusia, lingkungan, dan kebangsaan yang terwujud dalam pikiran, sikap, perasaan, perkataan, dan perbuatan berdasarkan norma-norma agama, hukum, tata krama, budaya, dan adat istiadat. Pengajaran Sejarah Nasional Indonesia mengarah kepada usaha pembentukan jiwa nasionalisme dan patriotisme serta menjadi warga negara yang baik, karena di dalamnya terdapat usaha menanamkan pemahaman nilai perjuangan bangsa.

Akan tetapi mempelajari sejarah seringkali belum dipahami sebagai upaya menumbuhkan sikap nasionalisme, padahal sikap optimisme terhadap sejarah sebagai disiplin ilmu yang menjanjikan pembentukan karakter akan nilai spiritual, dan kultural karena kajiannya memberikan pedoman terhadap keseimbangan hidup, harmoni, nilai, dan keteladanan dalam keberhasilan serta kegagalan dan cerminan bagi pengalaman kolektif dapat dijadikan petunjuk bagi kehidupan masa depan (Wiriaatmadja, 2002: 294).

Disamping itu, dijadikan sejarah sebagai mata pelajaran di sekolah pada dasarnya bertujuan agar siswa menyadari adanya keragaman pengalaman hidup pada masing-masing masyarakat dan adanya cara pandang yang berbeda terhadap masa lampau untuk memahami masa kini dan membangun pengetahuan serta pemahaman untuk menghadapi masa yang akan datang (Isjoni, 2007: 72).

Dalam sejarah tertulis pula perjuangan merebut dan mempertahankan kemerdekaan telah membawa korban jiwa, harta, tenaga dan pikiran.Para pejuang secara tulus dan ikhlas melakukan perjuangan, secara bersama-sama meskipun memiliki berbagai perbedaan misalnya 
kebudayaan, asal-usul, adat istiadat, tradisi bahasa, agama, suku bangsa dan mendirikan Negara Kesatuan Republik Indonesia.

Hal tersebut membuktikan bahwa para pejuang memiliki sikap nasionalisme, patriotisme dan semangat persatuan yang tinggi demi bangsanya. Dengan demikian, dalam bersikap dan bertindak didasari oleh keyakinan kebenaran nilai-nilai perjuangan 1945, misalnya membela persatuan dan kesatuan bangsa. Bagi mahasiswa di masa pembangunan sekarang ini, menanamkan dan memahami nilai-nilai perjuangan 1945 lebih sulit daripada generasi terdahulu.

Oleh sebab itu, usaha untuk mewariskan adalah memberikan materi yang berhubungan dengan nilai-nilai perjuangan bangsa Indonesia sampai mencapai kemerdekaan. Selanjutnya, dilakukan dengan mengadakan kegiatan peringatan hari-hari bersejarah nasional, mengadakan studi tour ke tempat peninggalan sejarah serta studi kritis untuk membentuk pola pikir mahasiswa dalam mengambil keputusan.

Hal ini dilakukan sebagai upaya pemahaman dan merekonstruksikan serta mengapresiasi peristiwa sejarah itu sendiri. Sehingga akan menimbulkan kesadaran sejarah dan wawasan kebangsaan yang memandang bangsa Indonesia terhadap diri bangsa dan lingkungannya, meliputi ideologis konstitusional, kewilayahan, sosial budaya dan kesejarahan tentang bangsa
Indonesia yang dimulai pada awal kebangkitan nasional dengan munculnya budi utomo sampai sumpah pemuda yang dapat memperkokoh eksistensi, identitas serta kepribadian bangsa untuk mewujudkan character building national melalui rasa bangga akan sejarahnya.

Kesadaran tentang perjalanan hidup masa lampau, akhirnya mampu memetakan identitas atau jatidiri manusia secara individual maupun manusia sebagai anggota suatu komunitas/kelompok, selain itu kesadaran sejarah juga dapat mengendalikan kecenderungan dari sifat keserakahan yang menggurita dari kemajuan teknologi dan industri. Kesadaran sejarah tidak berhenti pada persoalan tekstual masa lampau sebagai pengetahuan yang dipelajari, tetapi juga bagaimana mahasiswa berkembang didalam memahami konteks masa lalu itu dengan mengembangkan nalar analisis terhadap konteks persoalan kekinian, sebagai pertanggungjawaban bagi kehidupan.

Hal inilah konsepsi dari "kesadaran kenisbian" suatu sense of relativity, dan mengembangkan telaah historis dengan memahami dan menghayati hubungan antara perkembngan sejarah sebagai ilmu dengan perkembangan masyarakat (Soedjatmoko, 2010: 16-17). Bahkan Fitzgerald (2001) mengungkapkan bahwa tanpa kesinambungan masa lalu, masyarakat akan bubar, runtuh termasuk juga fungsi pemerintahan, hukum dan 
pendidikan. Berdasarkan uraian latar belakang masalah di atas, penulis tertarik untuk mengkaji mengenai hubungan antara pemahaman sejarah nasional indonesia dan wawasan kebangsaan dengan karakter mahasiswa (studi pada mahasiswa program studi pendidikan sejarah FKIP Universitas Galuh Ciamis).

\section{Metode Penelitian}

Penelitian ini dilaksanakan di Program Studi pendidikan Sejarah Fakultas Keguruan dan Ilmu Pendidikan Universitas Galuh Ciamis dengan estimasi waktu bulan November 2013 hingga bulan April 2014. Metode penelitian yang digunakan adalah ex-post facto. Penelitian korelasi ex-post facto bertujuan untuk mencari apakah terdapat hubungan antara dua variabel atau lebih dalam koefisisen korelasi.

Data penelitian diperoleh dari hasil sebaran test dan angket instrument. Pengambilan sampel dengan stratified randomsampling, yaitu sampel diambil dari populasi yang terlebih dahulu dikelompokan dalam sub-populasi, yaitu semester VI dan VIII.

\section{Hasil Dan Pembahasan}

Berdasarkan hasil analisis dengan menggunakan berbagai penghitungan dapat dinyatakan bahwa hipotesis telah terbukti kebenarannya. Adapun deskripsi tentang temuan-temuan yang diperoleh dalam penelitian, antara lain:

\section{Hubungan Pemahaman SNI $\left(X_{1}\right)$} dengan Karakter Mahasiswa (Y)

Berdasarkan hasil analisis, hubungan antara variabel pemahaman SNI $\left(\mathrm{X}_{1}\right)$ dengan variabel karakter mahasiswa (Y) ditunjukkan oleh koefisien korelasi sebesar 0.590. Nilai koefisien korelasi menunjukkan hubungan yang sedang karena nilai yang diperoleh tidakbegitu tinggi. Namun, variabel $\mathrm{X}_{1}$ dengan variabel $\mathrm{Y}$ dinyatakan memiliki hubungan yang positif.

Hubungan positif yang ditunjukkan oleh variabel $\mathrm{X}_{1}$ dengan variabel $Y$ ini berbanding lurus dengan hasil penghitungan koefisien regresi $b$ sebesar 0.159 dan konstanta a sebesar 100.876. Hasil penghitungan regresi dapat dinyatakan dalam persamaan garis regresi, yaitu $\widehat{\mathrm{Y}}=100.876+0.159 \mathrm{X}_{1}$. Selanjutnya, untuk mengetahui keberartian hubungan variabel $\mathrm{X}_{1}$ dengan variabel $\mathrm{Y}$ dilakukan dengan mengkonsultasi $t_{\text {hit }}$ terhadap $t_{\text {tab }}$ pada taraf signifikan 5\% dengan kriteria yang dikehendaki $t_{\text {hit }}>t_{\text {tab. }}$.

Berdasarkan hasil penghitungan menggunakan uji t diperoleh $t_{\text {hit }}(5.535)>$ $t_{\text {tab }}$ (1.663) sehingga dapat dinyatakan hubungan variabel $\mathrm{X}_{1}$ dengan variabel $\mathrm{Y}$ memiliki keberartian dan dapat digunakan untuk menggeneralisasi populasi variabel pemahaman sejarah nasional Indonesia dan variabel karakter mahasiswa. Selain itu, dilakukan 
pengujian koefisien determinasi $\left(\mathrm{r}^{2}\right)$ untuk mengetahui seberapa besar sumbangan yang diberikan variabel $\mathrm{X}_{1}$ terhadap variabel Y. berdasarkan hasil penghitungan diperoleh $r^{2}$ sebesar $34.80 \%$ terhadap variabel karakter mahasiswa. Hal ini juga berarti bahwa sisanya sebesar $65.20 \%$ variabel karakter mahasiswa dipengaruhi oleh faktor lain yang tidak dimasukkan sebagai unsur pendukung penelitian ini.

Analisis diatas tentang hubungan variabel $X_{1}$ dengan variabel $Y$ menunjukkan hubungan yang positif dan signifikan antara keduanya sehingga hasil penelitian dapat diberlakukan terhadap populasi penelitian. Keeratan hubungan variabel $\mathrm{X}_{1}$ dengan variabel $\mathrm{Y}$ ditunjukkan oleh tinggi atau rendahnya perubahan atau pengaruh yang diberikan variabel $\mathrm{X}_{1}$ terhadap variabel $\mathrm{Y}$ ditunjukkan oleh tinggi atau rendahnya persentase nilai pada koefisien determinasi $\left(\mathrm{r}^{2}\right)$.

Berdasarkan penghitungan regresi yang dinyatakan dalam persamaan garis regresi yaitu $\widehat{Y}=$ $100.876+0.159 \mathrm{X}_{1}$ diperoleh kesimpulan bahwa peningkatan 1 (satu) unit pemahaman sejarah nasional Indonesia diikuti dengan peningkatan karakter mahasiswa sebesar 0.159 pada konstanta 100.876. Hal ini sejalan dengan pendapat Arikunto (2009:118) bahwa pemahaman adalah proses menjadikan suatu pengetahuan menjadi milik dirinya dan pada akhirnya akan mempengaruhi proses berpikir dan bertindak individu. Kemampuan memahami sangat penting untuk mencapai pengetahuan prosedur, yaitu untuk memahami arti atau konsep, situasi serta fakta yang diketahuinya.

Pemahaman itu yang nantinya akan membentuk pola pikir, perilaku maupun tata kelakuan seseorang dalam kehidupan bermasyarakat. Pendapat serupa diungkapkan oleh Bloom (dalam Nugroho Putro, 1995: 15) yang memasukan pemahaman dalam ranah kognitif, artinya berkaitan dengan Intelligence Qoutient (IQ) yang dimiliki sehingga memungkinkan untuk dapat mencerna dan memaknai maupun menemukan makna yang terkandung didalamnya. Pemahaman tidak hanya sekedar kemampuan menerjemahkan, tetapi juga kemampuan untuk menafsirkan dan meramalkan dibalik yang tertulis (Sudjana, 1995: 24).

Pernyataan ini diperkuat oleh Sanjaya (2009) yang menguraikan beberapa indikator pemahaman, diantaranya kemampuan menerangkan secara verbal, mengetahui perbedaan, mengklasifikasikan objek, menerapkan hubungan antara konsep dan prosedur, memberikan contoh, menerapkan dan mengembangkan konsep. Menurut Sartono Kartodirjo (1997: 36), peranan sejarah Indonesia adalah sebagai sarana 
penting untuk pendidikan warga negara Indonesia terutama untuk menumbuhkan kesadaran nasionalnya dengan mengenal identitas bangsa melalui sejarahnya.

$$
\text { Dengan pengetahuan dan }
$$
pemahaman sejarah nasional Indonesia dan sejarah dunia, mahasiswa dapat mengerti dan memahami diri sendiri, sehingga mereka mengetahui arah yang harus dituju, dimana mahasiswa akan berpikir dan bergerak di masa depan. Dengan pemahaman di masa lampau yang benar, pasti akan dapat diwujudkan identitas dirinya sendiri, lagi pula akan memperoleh tujuan serta pengertian yang mendalam mengenai kedudukan dan fungsinya.

Berdasarkan uraian tersebut, dapat disimpulkan bahwa pemahaman sejarah nasional Indonesia berarti kemampuan mahasiswa untuk dapat menjawab soal-soal pada aspek kognitif terdiri dari kategori pengetahuan, pemahaman, aplikasi, analisis, sintesis dan evaluasi. Dari pemahaman sejarah nasional Indonesia ini, dapat diukur seberapa jauh tingkat pemahaman individu (mahasiswa) terhadap konsepkonsep, fakta-fakta substansi, materi sejarah nasional Indonesia dan diharapkan mampu mencapai tingkat pemahaman yang dicapai oleh mahasiswa sehingga dapat berpengaruh terhadap pembentukan karakter.
Pendapat yang telah dipaparkan tersebut tentang hubungan pemahaman sejarah nasional Indonesia dengan karakter mahasiswa sesuai dengan penelitian sebelumnya oleh Sukonsih (2002) dalam salah satu hasil risetnya menyatakan bahwa terdapat hubungan positif yang signifikan antara pemahaman sejarah nasional Indonesia dengan sikap demokrasi Pancasila yang ditunjukkan oleh $r_{\text {hit }}(0.665)>r_{\text {tab }}$ (0.196), dengan demikian hasil penelitian ini membuktikan terdapat hubungan positif yang signifikan antara pemahaman sejarah nasional Indonesia dengan karakter mahasiswa.

\section{Hubungan Wawasan Kebangsaan $\left(X_{2}\right)$} dengan Karakter Mahasiswa (Y)

Berdasarkan hasil analisis, hubungan antara variabel wawasan kebangsaan $\left(\mathrm{X}_{2}\right)$ dengan variabel karakter mahasiswa (Y) ditunjukkan oleh koefisien korelasi sebesar 0,604.Nilai koefisien korelasi ini menunjukkan hubungan yang positif dan kuat antara variabel $\mathrm{X}_{2}$ dengan variabel $\mathrm{Y}$.

Hal ini sebanding dengan hasil penghitungan koefisien regresi b sebesar 0.442 dan konstanta a sebesar 52.272. Artinya, peningkatan setiap satu unit wawasan kebangsaan akan diikuti oleh peningkatan karakter mahasiswa sebesar 0.442 dan konstanta a sebesar 52.272. Hasil penghitungan regresi tersebut 
dapat dinyatakan dalam persamaan garis regresi, yaitu $\widehat{Y}=52.272+0.442 \mathrm{X}_{2}$.

Selanjutnya, untuk mengetahui keberartian hubungan variabel $\mathrm{X}_{2}$ dengan variabel Y dilakukan dengan mengkonsultasi $t_{\text {hit }}$ terhadap $t_{\text {tab }}$ pada taraf signifikan 5\% dengan kriteria yang dikehendaki $t_{\text {hit }}>t_{t a b}$. Berdasarkan hasil penghitungan uji $t$ diperoleh yaitu $t_{\text {hit }}$ (6.867) $>t_{t a b}$ (1.663) sehingga dapat dinyatakan hubungan variabel $\mathrm{X}_{2}$ dengan variabel $\mathrm{Y}$ memiliki keberartian dan dapat digunakan untuk menggeneralisasi populasi variabel wawasan kebangsaan dan variabel karakter mahasiswa.

Selain itu, dilakukan pengujian koefisien determinasi $\left(\mathrm{r}^{2}\right)$ untuk mengetahui seberapa besar sumbangan yang diberikan variabel $\mathrm{X}_{2}$ terhadap variable Y. Berdasarkan hasil penghitungan diperoleh $r^{2}$ sebesar $36.50 \%$ terhadap variabel karakter mahasiswa. Hal ini juga berarti bahwa sisanya sebesar $63.50 \%$ variabel karakter mahasiswa dipengaruhi oleh faktor lain yang tidak dimasukkan sebagai unsur pendukung penelitian ini.

Analisis diatas tentang hubungan varibel $\mathrm{X}_{2}$ dengan variabel $\mathrm{Y}$ menunjukkan hubungan yang positif dan signifikan antara keduanya sehingga hasil penelitian dapat diberlakukan terhadap populasi penelitian. Keeratan hubungan variabel $\mathrm{X}_{2}$ dengan variabel $\mathrm{Y}$ ditunjukkan oleh tinggi atau rendahnya perubahan atau pengaruh yang diberikan variabel $\mathrm{X}_{2}$ terhadap variabel $\mathrm{Y}$ ditunjukkan oleh tinggi atau rendahnya persentase nilai pada koefisien determinasi $\left(\mathrm{r}^{2}\right)$.

$$
\text { Berdasarkan penghitungan }
$$

regresi yang dinyatakan dalam persamaan garis regresi yaitu $\widehat{Y}=52.272$ $+0.442 \mathrm{X}_{2}$ diperoleh kesimpulan bahwa peningkatan wawasan kebangsaan akan diikuti dengan peningkatan karakter mahasiswa sebesar 0.442 pada konstanta 52.272. Hasil ini sesuai dengan pendapat Tilaar yang mengacu dari pendapat Ernest Renan dalam esainya yang terkenal, yaitu Qu'est-ce qu'une nation?, yang mengatakan bahwa suatu bangsa merupakan satu jiwa atau suatu tingkah laku atas kesepahaman yang sukarela (2007: 28-29).

Pendapat ini didukung oleh Poespowadojo yang menyatakan bahwa wawasan kebangsaan akan menyadarkan warga negara akan pentingnya arti hidup bersama atas dasar persamaan hak dan kewajiban dihadapan hukum yang akan menjamin ketentraman hidup seluruh bangsa (1994: 6). Wawasan kebangsaan berasumsi pada kesamaan rasial, religius dan kebudayaan.

Oleh sebab itu, wawasan kebangsaan merupakan wadah yang menegaskan identitas masyarakat Indonesia yang serba majemuk dalam berbagai dimensi kulturalnya sehingga 
mampu menyadarkan warga negara akan pentingnya arti hidup bersama atas dasar persamaan hak dan kewajiban berdasarkan hukum yang berlaku.

Wawasan kebangsaan terbentuk sebagai produk sejarah dalam sejarah kebudayaan masyarakat Indonesia yang karena persamaan nasib, mereka bersatu dan berjuang bersama untuk mendirikan dan membangun bangsa (Poespowadojo, 1994: 33). Konsep wawasan kebangsaan Indonesia tertuang dalam ciri berikut: (1) keseimbangan lahir dan batin; (2) pemimpin yang bersatu jiwa dengan rakyat; (3) musyawarah antara rakyat dengan pemimpinnya dengan semangat gotong royong dan kekeluargaan (Djawamaku, 1985: 920-921).

Lebih lanjut, Sumardjoko (2002: 25) mengemukakan bahwa wawasan kebangsaan mempunyai ciri-ciri adalah (1) bersifat integralistik, kekeluargaan, (2) bersifat anti diskriminasi dan tidak ada konotasi etnis, (3) bersifat Bhineka Tunggal Ika dan (4) selalu terikat dengan wawasan nusantara. Wawasan kebangsaan adalah hasil perkembangan dari dinamika rasa kebangsaan dalam mencapai cita-cita bangsa, rasionalisasi rasa dan wawasan kebangsaan yang melahirkan suatu nasionalisme atau paham kebangsaan yaitu pikiran yang bersifat nasional, dimana suatu bangsa memiliki cita-cita kehidupan dan tujuan nasional serta memiliki karakter yang handal didalamnya meliputi aspek pengetahuan (cognitive), Perasaan (feeling), dan tindakan (action) sebagai bagian dari jati diri seorang mahasiswa yang mampu menumbuhkan semangat kebangsaan terhadap negara dan bangsanya. Berdasarkan uraian diatas, maka dapat dibuktikan bahwa seseorang yang memiliki wawasan kebangsaan yang baik/tinggi, maka akan memiliki karakter yang baik pula. Dengan kata lain, terdapat hubungan positif yang signifikan antara wawasan kebangsaan dengan karakter mahasiswa.

Berdasarkan kajian teori di atas, diperoleh kesimpulan bahwa secara teoritis terdapat hubungan antara wawasan kebangsaan dengan karakter mahasiswa. Selain itu, hubungan positif yang signifikan juga ditunjukkan oleh penelitian terdahulu, yaitu salah satu hasil riset Kian Amboro tahun 2013 bertema "Hubungan antara pemahaman sejarah nasional Indonesia dan sikap nasionalisme dengan kesadaran sejarah mahasiswa program studi pendidikan sejarah FKIP Universitas Muhammadiyah Metro Tahun Akademik 2013/2014 menghasilkan korelasi signifikan $t_{\text {hitung }}$ $(106,367)>t_{\text {tabel }}(1,654)$.

Dengan demikian, semakin memperkuat hasil penelitian ini bahwa terdapat hubungan positif yang signifikan antara wawasan kebangsaan dengan karakter mahasiswa. 
3. Hubungan Pemahaman SNI $\left(X_{1}\right)$ dan Wawasan Kebangsaan $\left(X_{2}\right)$ dengan Karakter Mahasiswa (Y)

Berdasarkan hasil analisis pada data variabel Pemahaman Sejarah nasional Indonesia $\left(\mathrm{X}_{1}\right)$ dan wawasan kebangsaan $\left(\mathrm{X}_{2}\right)$ dengan karakter mahasiswa (Y) diperoleh koefisien korelasi sebesar 0,605. Nilai koefisien korelasi ini menunjukkan hubungan yang positif dan kuat antara variabel $\mathrm{X}_{1}$ dan $\mathrm{X}_{2}$ dengan variabel $Y$.

Dari hasil penghitungan koefisien regresi $b$ diperoleh pemahaman sejarah nasional Indonesia sebesar 0,079, koefisien regresi wawasan kebangsaan sebesar 0,441 dan konstanta $a$ sebesar 50,215 . Hal ini mengandung pengertian bahwa peningkatan tiap satu unit pemahaman SNI akan diikuti oleh peningkatan karakter mahasiswa sebesar 0,079 dan peningkatan tiap satu unit wawasan kebangsaan akan diikuti oleh peningkatan karakter mahasiswa sebesar 0,441 pada konstanta $a$ sebesar 50,215. Hasil penghitungan regresi tersebut dapat dinyatakan dalam persamaan regresi ganda yaitu $\widehat{Y}=50,215+0,079 X_{1}$ $+0,441 X_{2}$.

Selanjutnya, untuk mengetahui keberartian hubungan variabel $\mathrm{X}_{1}$ dan $\mathrm{X}_{2}$ dengan variabel $\mathrm{Y}$ dilakukan dengan mengkonsultasikan $F_{\text {hit }}$ terhadap $F_{\text {tab }}$ pada taraf signifikansi $5 \%$ dengan kriteria yang dikehendaki $\quad F_{\text {hit }}>\quad F_{\text {tab }}$.
Berdasarkan hasil penghitungan menggunakan uji $F$ diperoleh $\left(F_{h i t}\right)$ $23,376>\left(F_{\text {tab }}\right) 3,111$. Hal ini sesuai dengan kriteria yang dikehendaki, sehingga dapat dinyatakan hubungan variabel $\mathrm{X}_{1}$ dan $\mathrm{X}_{2}$ dengan variabel $\mathrm{Y}$ memiliki keberartian dan dapat digunakan untuk menggeneralisasi populasi variabel pemahaman SNI, variabel wawasan kebangsaan dan variabel karakter mahasiswa.

Selain itu, dilakukan pengujian koefisien determinasi $\left(\mathrm{r}^{2}\right)$ untuk mengetahui seberapa besar sumbangan yang diberikan kedua variabel bebas terhadap variabel terikat, dalam hal ini untuk menguji sumbangan variabel $\mathrm{X}_{1}$ dan $\mathrm{X}_{2}$ terhadap variabel $\mathrm{Y}$. Berdasarkan hasil perhitungan diperoleh $r^{2}$ sebesar $36,60 \%$. Artinya, variabel pemahaman sejarah nasional Indonesia dan variabel wawasan kebangsaan secara bersama memberikan sumbangan yang cukup terhadap variabel karakter mahasiswa yaitu $36,60 \%$.

Dengan demikian, sisanya sebesar 63,40 \% variabel karakter mahasiswa dipengaruhi oleh faktor lain yang tidak dimasukkan sebagai unsur pendukung dalam penelitian ini. Setelah mengkaji beberapa penelitian terdahulu yang tidak dimasukkan sebagai unsur pendukung dalam penelitian ini, namun turut memberikan kontribusi terhadap karakter mahasiswa. Analisis di atas 
tentang hubungan variabel $\mathrm{X}_{1}$ dan variabel $\mathrm{X}_{2}$ dengan variabel $\mathrm{Y}$ menunjukkan hubungan yang positif dan signifikan antara variabel bebas dengan variabel terikat sehingga hasil penelitian dapat diberlakukan terhadap populasi penelitian.

Keeratan hubungan variabel $\mathrm{X}_{1}$ dan variabel $\mathrm{X}_{2}$ dengan variabel $\mathrm{Y}$ ditunjukkan oleh tinggi atau rendahnya nilai pada koefisien korelasi (r) yang dihasilkan. Sedangkan sumbangan perubahan atau pengaruh yang diberikan variabel $X_{1}$ dan variabel $X_{2}$ secara bersama terhadap variabel Y ditunjukkan oleh tinggi atau rendahnya persentase nilai pada koefisien determinasi $\left(\mathrm{r}^{2}\right)$.

Berdasarkan penghitungan regresi yang dinyatakan dalam persamaan garis regresi, yaitu $\widehat{Y}=50,215$ $+0,079 \mathrm{X}_{1}+0,441 \mathrm{X}_{2}$ diperoleh kesimpulan bahwa peningkatan tiap 1 (satu) unit pemahaman sejarah nasional Indonesia akan diikuti oleh peningkatan karakter mahasiswa sebesar 0,079 dan peningkatan tiap satu wawasan kebangsaan akan diikuti oleh peningkatan karakter mahasiswa sebesar 0,441 pada konstanta sebesar 50,215.

Hasil analisis ini sesuai dengan pendapat Gottschalk bahwa dalam pembelajaran sejarah terdapat dua unsur yang dapat diaktualisasikan, yaitu (1) pembelajaran (instruction) dan pendidikan intelektual (intellectual training) meliputi latihan berpikir kritis, menarik kesimpulan, menarik makna dan nilai dari peristiwa; (2) pembelajaran dan pendidikan moral bangsa (civil society) yang berorientasi pada pendidikan kemanusiaan (humaniora) dengan memperhatikan nilai-nilai dan norma-norma (1975: 10). Sehingga melalui pembelajaran sejarah akan membentuk kepribadian yang kuat, mengerti sesuatu agar dapat menambah pada karakter mahasiswa.

Lebih lanjut oleh Anhar Gonggong (dalam Latief, 2006: 49) bahwa kesadaran sejarah ternyata sangat berkaitan erat dengan peristiwa sejarah dan fakta sejarah. Jadi fakta sejarah dapat dikatakan merupakan pintu masuk paling awal untuk memupuk kesadaran sejarah suatu masyarakat, dan dapat dipastikan berdasarkan kenyataan yang hampir berlaku umum bahwa keringnya pengetahuan fakta sejarah yang dimiliki oleh masyarakat, sudah dapat diprediksikan adalah masyarakat yang berada di luar kamar kesadaran sejarah.

Pemahaman sejarah nasional Indonesia dan wawasan kebangsaan akan memotivasi seorang mahasiswa untuk mengetahui,mempelajari, mengerti serta dapat menginterpretasi suatu objek peristiwa sejarah dengan bijak dan benar hingga mampu menimbulkan semangat kebangsaan atau semangat patriotisme yang tinggi sebagai 
bagian dari karakter seorang mahasiswa yang peduli akan sejarah dan tanah airnya. Dengan kata lain, terdapat hubungan positif yang signifikan antara pemahaman sejarah nasional Indonesia dan wawasan kebangsaan dengan karakter mahasiswa.

Hal serupa dikemukakan juga oleh Ankersmit (1987: 350-351) kesadaran sejarah pada dasarnya muncul karena keterbukaan manusia akan adanya perubahan yang mendalam. Keterbukaan pemikiran ini termasuk terbuka pada kenyataan bahwa sejarah hakikatnya adalah berbicara konsep perubahan, konsep perubahan yang tidak dapat dilepaskan dari konsep waktu, masa lalu, masa kini, dan masa yang akan datang. Setiap perubahan yang terjadi di dalam berjalannya waktu mengajarkan manusia untuk melakukan perenungan atau refleksi. Refleksi ini yang menurut Hariyono (1995:37-38) melahirkan pemahaman apa yang lampau dan apa yang kini, sehingga manusia mampu Memproyeksikan suatu tindakan untuk mengantisipasi masa depan.

Pendapat dan uraian di atas, sejalan dengan hasil penelitian ini yang menunjukkan adanya hubungan positif yang signifikan antara variabel pemahaman sejarah nasional Indonesia $\left(\mathrm{X}_{1}\right)$ dan wawasan kebangsaan $\left(\mathrm{X}_{2}\right)$ dengan karakter mahasiswa (Y), yang ditunjukan dengan besarnya nilai koefisien korelasi (r) sebesar 0,605. Kenyataan tersebut diatas didukung juga oleh hasil penelitian yang dilakukan Wahyu Mustakim tahun 2008 dengan tema pengaruh penerapan pendidikan karakter di sekolah terhadap perilaku akademik siswa kelas XI teknik komputer jaringan di SMK Piri 1 Yogyakarta.

Dalam penelitiannya untuk mengetahui penerapan pendidikan karakter yang ada di SMK PIRI 1 Yogyakarta. Tujuan yang lain adalah untuk mengetahui pengaruh penerapan pendidikan karakter di sekolah terhadap perilaku akademik siswa kelas XI Teknik Komputer Jaringan di SMK PIRI 1 Yogyakarta. Jenis penelitian iniadalah penelitian expost facto dengan menggunakan metode penelitian campuran (mixed methods).

Tempat penelitian di SMK PIRI 1 Yogyakarta. Subjek penelitian adalah siswa kelas XI Teknik Komputer Jaringan. Analisis yang digunakan meliputi analisis data kuantitatif dan kualitatif. Analisis untuk menguji hipotesis digunakan uji $\mathrm{t}$ yang sebelumnya data dilakukan uji normalitas, homogenitas dan linearitas. Analisis data kualitatif meliputi pengumpulan data, reduksi data, penyajian data dan verifikasi data.

Berdasarkan hasil yang didapatkan dari analisa kualitatif, ada pengaruh antara penerapan pendidikan 
karakter terhadap perilaku akademik siswa. Besarnya pengaruh yang terjadi dari penerapan pendidikan karakter yang dilakukan oleh pihak sekolah adalah sebesar 39,7\%. Hasil tersebut didukung dengan data kualitatif yang dapat disimpulkan bahwa penerapan pendidikan karakter memiliki pengaruh terhadap perkembangan perilaku akademik siswa.

Berdasarkan hasil penelitian yang relevan tersebut, dapat disimpulkan bahwa pemahaman akan sejarah (aspek kognitif) memberikan kontribusi dalam mempengaruhi dan menjelaskan variabel karakter mahasiswa. Pada intinya semakin tinggi pemahaman sejarah mahasiswa, akan semakin baik/tinggi pula karakternya. Dengan kata lain, terdapat hubungan positif yang signifikan antara pemahaman sejarah dengan karakter mahasiswa.

Pemahaman yang mencakup kemampuan menangkap makna dan arti dari bahan yang dipelajari. Pemahaman sejarah berarti kemampuan mahasiswa untuk dapat menjawab soal-soal pada aspek kognitif yang terdiri dari kategori pengetahuan, pemahaman, aplikasi, analisis, sintesis dan evaluasi. Dengan pemahaman di masa lampau yang benar, akan dapat diwujudkan identitas dirinya sendiri, selain itu akan memperoleh tujuan serta pengertian yang mendalam mengenai kedudukan dan fungsinya.

\section{Penutup}

\section{A. Keterbatasan Penelitian}

Penelitian ini telah dilaksanakan berdasarkan metode dan prosedur penelitian yang telah baku, sehingga segala aspek yang bersifat metodologi telah terpenuhi. Namun tentu masih terdapat beberapa hal yang dapat mempengaruhi hasil penelitian ini. Hal-hal tersebut adalah:

1. Pemilihan variabel penelitian, populasi dan sampel penelitian serta instrumen penelitian telah dilandasi teori yang cukup memadai. Selain itu, pembuktian secara empiris di lapangan secara ilmiah telah dipenuhi. Namun demikian, hasil temuan dalam penelitian ini tidak dapat berlaku secara umum, kecuali pada populasi yang relatif sama atau hampir sama kondisinya.

2. Instrumen penelitian yang digunakan dalam pengumpulan data tentu masih terdapat keterbatasan serta tidak dapat diberlakukan secara umum. Sehingga kebenarannya masih bersifat tentatif dan terbatas pada populasinya yaitu pada Program Studi Pendidikan Sejarah FKIP Universitas Galuh Ciamis Tingkat III semester VI (45 mahasiswa) dan Tingkat IV semester VIII (65 mahasiswa).

3. Kesediaan, kejujuran dan kesanggupan responden dalam menanggapi pernyataan dan menjawab pertanyaan belum sepenuhnya dapat dipercaya 100\%. Jawaban tertulis tidak sepenuhnya dapat mendeteksi apa yang 
sesungguhnya ada dalam diri responden, meskipun dalam petunjuk pengisian jawaban dan kondisi yang dimunculkan dalam proses pengumpulan data mengarahkan responden untuk mengisi secara objektif dan sejujur-jujurnya.

Masih adanya beberapa keterbatasan yang dapat mempengaruhi dan memberikan kontribusi terhadap variabel karakter mahasiswa, selain variabel pemahaman sejarah nasional Indonesia dan wawasan kebangsaan yang tidak diteliti dan berada di luar penelitian ini.

\section{B. Kesimpulan}

Berdasarkan kajian teori, hasil penelitian dan pembahasan di atas maka dapat disimpulkan sebagai berikut:

1. Terdapat hubungan positif antara pemahaman SNI $\left(\mathrm{X}_{1}\right)$ dengan karakter mahasiswa (Y) ditunjukkan oleh hasil penghitungan koefisien regresi $b$ sebesar 0,159, dan koefisien korelasi sebesar 0,590. Dengan menggunakan uji $t$ diperoleh kriteria yang dikehendaki yaitu $t_{\text {hit }}(5,535)>t_{\text {tab }}(1,663)$ dengan taraf signifikansi 5\%, serta adanya koefisien determinasi yang menyatakan sumbangan pemahaman SNI terhadap karakter mahasiswa sebesar 34,80\%.

2. Terdapat hubungan positif antara wawasan kebangsaan dengan karakter mahasiswa. Ditunjukkan hasil perhitungan koefisien regresi sebesar 0,442, dan koefisien korelasi sebesar
0,604. Dengan menggunakan uji $t$ diperoleh kriteria yang dikehendaki yaitu $t_{\text {hit }}(6,867)>t_{\text {tab }}(1,663)$ dengan taraf signifikan 5\%, serta adanya koefisien determinasi yang menyatakan sumbangan wawasan kebangsaan terhadap karakter mahasiswa sebesar $36,50 \%$.

3. Terdapat hubungan antara pemahaman SNI dan wawasan kebangsaan dengan karakter mahasiswa dapat dinyatakan positif dan signifikan. Ditunjukkan hasil penghitungan koefisien regresi pemahaman SNI sebesar 0,079, koefisien regresi wawasan kebangsaan sebesar 0,441 dan koefisien korelasi sebesar 0,605. Dengan uji $\mathrm{F}$ diperoleh kriteria yang dikehendaki yaitu $F_{\text {hit }}(23,376)>$ $F_{\text {tab }}(3,111)$ dengan taraf signifikan $5 \%$ serta adanya koefisien determinasi yang menyatakan sumbangan pemahaman reformasi terhadap sikap demokrasi sebesar $36,60 \%$.

Sumbangan Relatif (SR) variabel pemahaman sejarah nasional Indonesia ( $\mathrm{X}_{1}$ terhadap karakter mahasiswa $(\mathrm{Y})$ sebesar 3,95\% dan variabel wawasan kebangsaan $\left(\mathrm{X}_{2}\right)$ terhadap variabel karakter mahasiswa (Y) sebesar 96,05\%. Sumbangan Efektif (SE) variabel pemahaman SNI $\left(\mathrm{X}_{1}\right.$ terhadap karakter mahasiswa $(\mathrm{Y})$ sebesar 0,53\% variabel wawasan kebangsaan $\left(\mathrm{X}_{2}\right)$ terhadap variabel karakter mahasiswa (Y) sebesar $12,87 \%$. 


\section{Daftar Pustaka}

Abdullah, Taufik, Abdurrahman Surjomihardjo. 1985. Ilmu Sejarah dan Historiografi.Jakarta: Gramedia.

Ali, R. Moh. 2005. Pengantar Ilmu Sejarah Indonesia.Yogyakarta: LkiS

Anderson, Benedict. Tanpa Tahun. Imagined Communities Komunitas-Komunitas Terbayang. Penerjemah Omi Intan Naomi. 2008. Yogyakarta: Pustaka Pelajar.

Ankersmit, F.R. 1984.Refleksi Tentang Sejarah; Pendapat-Pendapat Modern tentang Filsafat Sejarah. Terjemahan Dick Hartoko. 1987. Jakarta: Gramedia

Arikunto, Suharsimi. 2009. Dasar-Dasar Evaluasi Pendidikan. Jakarta: Bumi Aksara

Ary, Donald., L.C. Jacobs., A. Razavieh. Tanpa Tahun. Pengantar Penelitian dalam Pendidikan.Terjemahan oleh Arief Furchan. 2011. Yogyakarta: Pustaka Pelajar

Azwar, Saifuddin. 2012. Reliabilitas dan Validitas. Yogyakarta: Pustaka Pelajar

.2012.Tes Prestasi : Fungsi dan Pengembangan Pengukuran Prestasi Belajar. Yogyakarta: Pustaka Pelajar

Budiyono. 2003. Metodologi Penelitian Pendidikan. Surakarta: Sebelas Maret University Press.

2009. Statistika Untuk Penelitian. Surakarta: Program Pascasarjana Universitas Sebelas Maret.

\section{Penelitian Hasil} Belajar. Surakarta: Program Pascasarjana Universitas Sebelas Maret.

Collingwood, R.G. 1980. Idea Sejarah. Terjemahaan M. Yusuf Ibrahim. 1985/ Kuala Lumpur: Dewan Bahasa dan Pustaka Kementrian Pelajaran Malaysia
Daliman. 2012. Manusia \& Sejarah. Yogyakarta: Ombak

Direktorat Jenderal Kesatuan Bangsa dan Politik Departemen Dalam Negeri, 2007, Peraturan Menteri Dalam Negeri Nomor39 Tahun 2007 tentang Pedoman Fasilitasi Organisasi Kemasyarakatan Bidang Kebudayaan, Keraton, danLembaga Adat dalam Pelestarian dan Pengembangan Budaya Daerah, Jakarta.

Edi Sedyawati, 2007, Keindonesiaan dalam Budaya: Buku 1 Kebutuhan Membangun Bangsa yang Kuat, Jakarta: Wedatama Widya Sastra.

Gottschalk, Louis. 1969. Mengerti Sejarah. Terjemahan Nugroho Notosusanto. 2008. Jakarta: UI Press

Haryanto, Samsi. 1994. Pengantar Teori Pengukuran Kepribadian. Surakarta: Sebelas Maret University Press.

Hasan, S. Hamid. 2011. History Education As na Educational Medium to Embody The Spirit of Nationality. Historia; International Journal of History Education. Vol XII. (1) 53-63.

Hellius Sjamsuddin. 1996. Pengantar Ilmu Sejarah. Jakarta: Depdikbud.

Kartodirdjo, Sartono. 1992. Pendidikan Ilmu Sosial Dalam Metodologi Sejarah. Jakarta: Gramedia

Kuntowijoyo. 2008. Penjelasan Sejarah (Historical Explanation). Yogyakarta: Tiara Wacana.

Kahin, G.MC. Turman. 1995. Nasionalisme and Revolution Indonesia, terjemahan UNS press bekerjasama dengan Pustaka Sinar Harapan.

Koentjaraningrat. 1984. Kebudayaan Mentalitas dan Pembangunan, Cet. ke-11. Jakarta: Gramedia,

L.R. Retno Susanti. 2012. Membangun Pendidikan Karakter Di Sekolah Melalui Kearifan Lokal, Makalah Seminar Kearifan Lokal.

Mulyono. 2011. National Integration and Its Process in Indonesia. Historia; 
International Journal of History Education.Vol. XII, (1) 1-12.

Ohmae, Kenichi. 2002. Hancurnya Negara Bangsa; Bangkitnya Negara Kawasan dan Geliat Ekonomi Regional di Dunia Tak Terbatas.Yogyakarta: Qalam

Prabawati, Sawitri. 1999.Hubungan Antara Pemahaman terhadap Mata Kuliah Sejarah Pemikiran Modern dan Mata Kuliah Manusia dan Kebudayaan Indonesia dengan Wawasan Kebangsaan Mahasiswa Fakultas Sastra, Tesis UNS.

Ridwan.2007 Rumus dan Data Untuk Penelitian.Bandung: Alfabeta.

Rokhman, Nur. 1999.Sumbangan Wawasan Kebangsaan dan Penghayatan NilaiNilai Kepahlawanan terhadap Pembentukan Sikap Bela Negara Siswa Pribumi dan Non Pribumi SMU Yogyakarta, Tesis UNS.

Sartono Kartodirdjo.1994.Kebudayaan Pembangunan dalam Perspektif Sejarah,Gadjah Mada University Press,Yogyakarta,. .1984.Pembangunan Bangsa tentang Nasionalisme, 1994, Kesadaran dan Kebudayaan Nasional, Yogyakarta: Aditya Media.

Sibarani, Robert. 2012. Kearifan Lokal. Jakarta: ATL

Sudjana, Nana. 1996.Penilaian Hasil Proses Belajar Mengajar. Bandung: Remaja Rosdakarya.

Sugiyono. 2007.Metode Penelitian Administrasi. Bandung: Alfabeta.

Sumardjoko, Bambang. 1995.Wawasan Kebangsaan dan Pengembangan Bangsa, Buletin Akademik no.03/Th XIII/1995

Suyanto, 2011. "Urgensi Pendidikan Karakter" di laman resmi Direktorat Jenderal Manajemen Pendidikan Dasar dan Menengah. (www.educationplanner.org). http://www.museum.pusaka- nias.org/2013/02/pembentukan-

karakter-berbasis-kearifan.html

Sudjana, Nana. 1995. Penilaian Hasil Proses Belajar Mengajar. Bandung: Remaja Rosdakarya.

Sugiyono. 2012. Metode Penelitian Kuantitatif, Kualitatif, dan $R$ \& D. Bandung: Alfabeta

Sukardi.2011. Metodologi Penelitian Pendidikan Kompetensi dan Praktiknya. Jakarta: Bumi Aksara

Umar, Husein. 2000. Evaluasi Kinerja Perusahaan, Jakarta: PT Gramedia Pustaka Utama.

Undang-Undang No. 20 Tahun 2003. Tentang Sistem Pendidikan Nasional, Jakarta: Departemen Pendidikan Nasional

Widja, I Gde. 2002. Menuju Wajah Baru Pendidikan Sejarah. Yogyakarta: Lappera Pustaka Utama

Wijaya, Cece, dkk. 2000. Statistika Penelitian. Bandung: PT. Remaja

\section{Sumber Jurnal, Tesis dan Surat Kabar:}

Nugroho Putro, Herry Porda. 1995. Kontribusi Pemahaman Makna Sejarah Indonesia Abad XIX dan Kesadaran Sejarah Terhadap Sikap Kepemimpinan Mahasiswa Pendidikan Sejarah. Tesis. Surakarta: PPs IKIP Jakarta KPK UNS Surakarta. (Unpublished)

Tjarsono, Idjang. 2013. Demokrasi Pancasila dan Bhinneka Tunggaal Ika Solusi Heterogenitas. Jurnal Transnasional, Vol. 4, No. 2.

Suhadi, 2002.Hubungan Antara Wawasan Kebangsaan dan Pemahaman Sejarah Nasional Indonesia dengan Sikap Terhadap Integrasi Nasional Siswa Sekolah Menengah Kejuruan di Kabupaten Sragen.Tesis. Surakarta: PPs Universitas Sebelas Maret. (Unpublished)

Sukardi. 2002. Hubungan antara Pemahaman Sejarah Pergerakan Nasional Indonesia dan Sikap Terhadap Nilai Sosio Budaya dengan 


Wawasan Kebangsaan Pada
Mahasiswa Program $r$ Studi
Pendidikan Sejarah FKIP Universitas
PGRI Palembang. Tesis. Surakarta:
PPs Universitas Sebelas Maret.
(Unpublished)

Sukonsih, Cucu Siti. 2002. Hubungan Pemahaman Ideologi Pancasila dan Pemahaman Sejarah Nasional Indonesia dengan Sikap Demokrasi Pancasila Pada Mahasiswa Jurusan Pendidikan Ilmu Pengetahuan Sosial Universitas Veteran Bangun Nusantara Sukoharjo. Tesis. Surakarta: PPs Universitas Sebelas Maret(Unpublished)

Sumarjoko, Bambang. 1995. Wawasan Kebangsaan dan Pembangunan Bangsa.Jurnal Akademika, Nomor 33.

Sunardi. 2002. Hubungan Sikap Terhadap Pembauran dan Pemahaman Sejarah Nasional Indonesia dengan Sikap Nasionalisme Siswa: Penelitian Pada Siswa SMU Kristen se-Kota Salatiga. Tesis. Surakarta: PPs Universitas Negeri Jakarta KPK UNS Surakarta (Unpublished) 